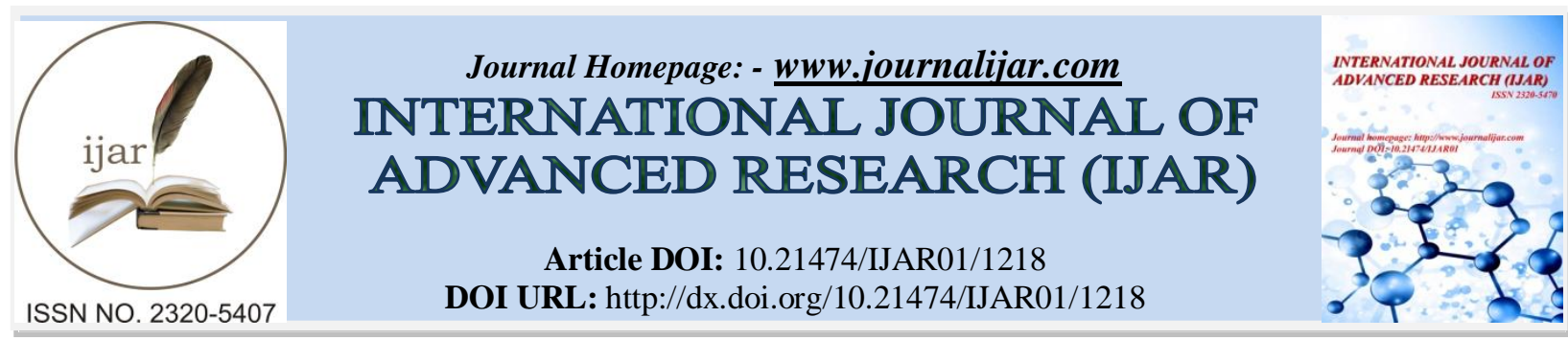

RESEARCH ARTICLE

\title{
A COMPREHENSIVE REVIEW ON HABITAT OF MICROBIAL COMPARISON BETWEEN NORMAL ORAL CAVITY AND PATIENTS HAVING ORAL CANCERS.
}

Satarupa Banerjee ${ }^{1}$, Sandhimita Mondal ${ }^{1 *}$, Suvakshan Dutta ${ }^{1}$ and Subir Ganguly ${ }^{2}$.

1. Department of Microbiology, Techno India University, EM-4, Sector-V, Salt Lake, Kolkata-700091, West Bengal, India.

2. Radiations \& Clinical Oncologist, R. G. Kar Medical College, Kolkata, West Bengal, India.

\section{Manuscript Info}

Manuscript History

Received: 18 June 2016

Final Accepted: 19 July 2016

Published: August 2016

Key words:-

Oral cavity, Microorganisms,

Carcinogens, Oral cancer, Comparison.

\begin{abstract}
There are numerous bacterial species within human body, of which several are unknown. A major habitation of bacteria including microfloras and opportunistic pathogens are present in the oral cavity. Our purposes were :(i) types of bacterial species present in the normal oral cavity of human; (ii) types of opportunistic pathogens present in the oral cavity; (iii) Chances of the pathogens to initiate an oral cancer; (iv) comparative study between the bacteria in normal cavity and patients having oral cancers. Some bacteria may cause infections depending on preferable conditions. Infections include inflammation, sensitivity, redness, and some may have carcinogen mutated genes. Infections causing inflammations may be the most consequential preventable cause of oral cancer. Microbial populations on mouth mucosa differ between salubrious and malignant sites. Approximately, 87-90\% of the oral cancer throughout the World. Certain oral bacterial species are also linked with malignancies due to their ability to induce chronic inflammation. Different bacteria have been proposed to induce carcinogenesis either through induction of chronic inflammation or by interference, either directly or indirectly, with eukaryotic cell cycle and signalling pathways, or by metabolism of potentially carcinogenic substances. The vicissitudes in micro-flora on oral mucosa commence after cancerous alteration, due to change in $\mathrm{pH}$, irregularity of lesion surface and broken bulwark mechanism of the oral mucosa. This may lead both local and systemic infections because of debilitated immune system by chemotherapy, irradiation, and surgery.
\end{abstract}

Copy Right, IJAR, 2016,. All rights reserved.

\section{Introduction:-}

Oral cancer is an ecumenical burden. Oral Cancers have become epidemic and ranks $6^{\text {th }}$ ecumenically (Khajuria N, Metgud R, et al., 2016). Some human oral micro-flora plays a role in carcinogenesis. Despite the erudition about relationship between micro-flora and oral cancer is still sceptical, a few postulations and theories have been made. Traditionally it has been cerebrated that mouth mucosa, the tongue, and the pharynx harbour characteristic bacterial pathogens causing chronic inflammation and focal infections (Jukka H. Meurman et al., 2010). One of the key 
features in many chronic diseases including cancer is inflammation. In general, infective inflammations have been presumed to be involved in the pathogenesis of approximately 15-20\% of human malignancies (Jukka H. Meurman et al., 2010).

The review emphasises on the comparative study and the mechanisms of actions of the microorganisms present in the normal oral cavity and the patient suffering from oral cancers, and are detected in the preliminary stage. The entire discussion and description also co -relates the mode of action of the normal micro-flora of the normal oral cavity which when under certain circumstances changes to be opportunistic pathogens, and may trigger the genes which are having carcinogenic properties.

\section{Factors affecting the growth of microorganisms in oral cavity:-}

$\checkmark$ Temperature,

$\checkmark$ REDOX Potential / Anaerobiosis,

$\checkmark \mathrm{pH}$,

$\checkmark$ Nutrients (endogenous \& exogenous (diet)),

$\checkmark$ Host Defences (Innate \& Acquired immunity),

$\checkmark$ Host genetics (changes in immune response, etc.),

$\checkmark$ Antimicrobial agents \& inhibitors.

\section{Risk factors of oral cancers:-}

Cancer Research shows the following risk factors for oral cancer:

$\checkmark$ Smoking tobacco - cigarettes, pipes and cigars.

$\checkmark$ Smokeless tobacco (chewing tobacco) - e.g. snuff, gutkha, etc.

$\checkmark$ Betel quid - with or without tobacco.

$\checkmark$ Excessive alcohol consumption.

$\checkmark$ Prior history of oral / aerodigestive cancers.

$\checkmark$ Age - Increasing age is a risk but oral cancer can occur at any age.

$\checkmark$ Poor diet - deficiencies, especially of certain minerals and vitamins including A, C and E;

$\checkmark$ Beta carotene is protective.

$\checkmark$ Sun exposure (especially for lip cancer).

$\checkmark$ Human papillomavirus and immunosuppression.

$\checkmark$ Potentially malignant oral disorders (Loesche, 1986).

\section{Micro-floral habitat in oral cavity:-}

Oral cavity does not maintain homogeneous conditions for colonisation of micro-organisms. The mucosal surface, such as lips, cheek and tongue as well as teeth has a distinct habitat of microbes due to their shapes, biological properties, conditions for growth of microbial communities [65].

Human mouth or the oral cavity always remains bathed with saliva, which has a distinct effect on the ecology of mouth ( Taylor \& Francis et al., 2000). Microorganisms generally seen in the oral cavity include staphylococci, streptococci (Streptococcus mutans), Lactobacillus acidophilus, Actinomyces odontolyticus, anaerobic spirochetes, and vibrios etc. (Marsh, 1989). 
Table 1:- Principal bacterial genera found in the healthy oral cavity (Table 1- [50]).

\begin{tabular}{|c|c|c|c|}
\hline \multicolumn{2}{|c|}{ GRAM POSITIVE } & \multicolumn{2}{|c|}{ GRAM NEGATIVE } \\
\hline Cocci & Rods & Cocci & Rods \\
\hline $\begin{array}{l}\text { Abiotrophia } \\
\text { Peptostreptococcus } \\
\text { Streptococcus } \\
\text { Stomatococcus }\end{array}$ & $\begin{array}{l}\text { Actinomyces } \\
\text { Bifidobacterium } \\
\text { Cornybacterium } \\
\text { Eubacterium } \\
\text { Lactobacillus } \\
\text { Propionibacterium } \\
\text { Pseudoramibacter } \\
\text { Rothia }\end{array}$ & $\begin{array}{l}\text { Moraxella } \\
\text { Neisseria } \\
\text { Veillonella }\end{array}$ & $\begin{array}{l}\text { Campylobacter } \\
\text { Capnocytophaga } \\
\text { Eikenella } \\
\text { Fusobacterium } \\
\text { Haemophilus } \\
\text { Selenomonas } \\
\text { Treponema } \\
\text { Wolinella } \\
\text { Prevotella }\end{array}$ \\
\hline
\end{tabular}

\section{Mouth pH and oral microorganisms:-}

The optimum $\mathrm{pH}$ of saliva is between $\mathrm{pH} 6.75-7.25$, which stimulates the growth of the Micro-organisms. Ionic composition of saliva promotes its buffering properties and its ability to demineralise enamel. The mode of influence by these components to the micro-organisms is:

$\checkmark$ Acting as primary sources of nutrients (carbohydrates and proteins) which foster the magnification of the denizen micro-flora without inducing a damaging $\mathrm{pH}$ (Beighton D, Smith K, Hayday H et al., 1986).

$\checkmark$ Changes in $\mathrm{pH}$ may correspond the opportunistic pathogens to proliferate and may lead to septic symptoms like inflammations, redness, infections (Van der Hoeven JS et al., 1998).

$\checkmark$ The vicissitudes in micro-flora on oral mucosa commence after cancerous alteration, due to change in $\mathrm{pH}$, irregularity of lesion surface and broken bulwark mechanism of the oral mucosa.

\section{The fluid: saliva and oral microorganisms:-}

The saliva is majorly composed of proteins and glycoproteins such as, amylase, mucin, immunoglobulins (mainly SIgA), lysozyme, lactoferrin and sialoperoxidase (Gibbons RJ. 1989). Due to the composition of saliva, it influences the oral micro-flora by:

$\checkmark$ Adherence involves specific intermolecular interactions between adhesions on the surface of the microorganism and receptors in the acquired pellicle. The microorganisms selectively attach and grow on certain surfaces (Lamont RJ, Jenkinson HF, 2000).

$\checkmark$ Cumulative microorganisms facilitate their clearance from the oral cavity by swallowing; the flow of saliva will also rinse away weakly- adherent cells.

$\checkmark$ Attaching to the surface of microorganisms to mask bacterial antigens, thereby making the organism appear more akin to host. Prohibiting the attachment and growth of exogenous microorganisms, with the ability of host defences [24]. 


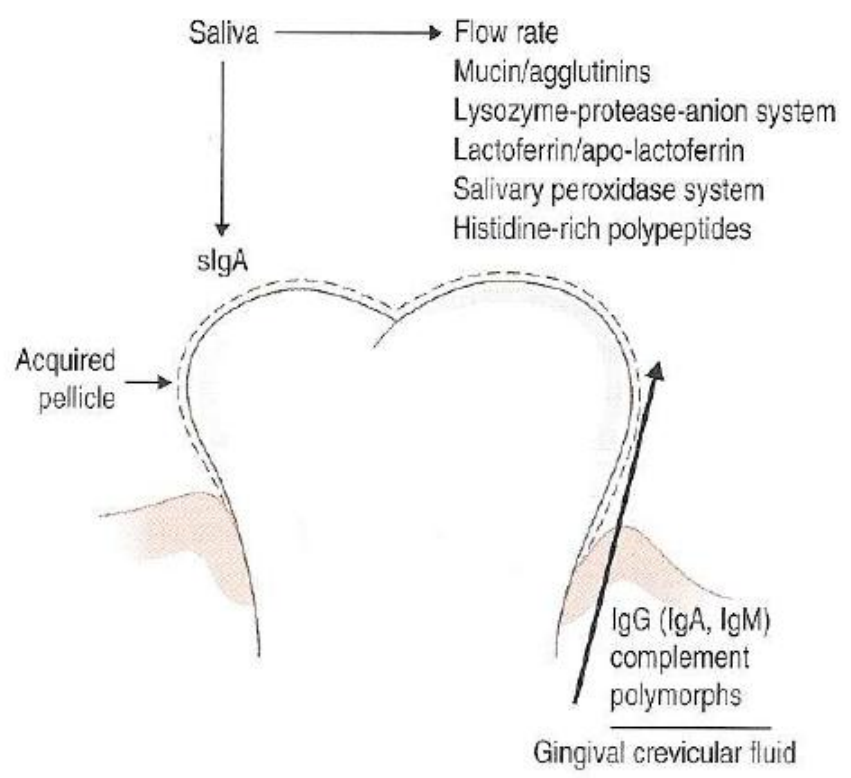

Fig. 1:- Figure shows the composition of saliva enhancing the growth of Oral micro-organisms (Marsh \& Martin et al., 1992).

The soft tissue: enamel and oral microorganisms:-

In children the oral cavity is sterile. But soon is affected by facultative aerobic organisms like S.salivarius. Gradually the flora becomes complex due to new habitats. Mouth enamels are the soft tissues of oral cavity containing distinct types of micro-floras and other microorganisms, some may are opportunistic pathogens. The dental enamel is made of inorganic minerals which mostly consist of calcium and phosphate. The proteins of the saliva bind to the most common calcium phosphates, hydroxyapatite, through an electrostatic interaction. Some of these proteins are the phosphoproteins: statherin, histatin, and proline-rich proteins (PRPs) (Wiki, micro. "Introduction To Mouth", 2011).

The part of hard tissues:- teeth and oral microorganisms:-

Non-shedding surface enabling large masses of microbes to accumulate (dental plaque biofilm). Teeth have distinct surfaces for microbial colonisation (e.g. Smooth surfaces, pits \& fissures etc) will support distinct micro flora due to their biological properties (M.R.Milward et al., and Marsh \& Martin et al,. 1992).

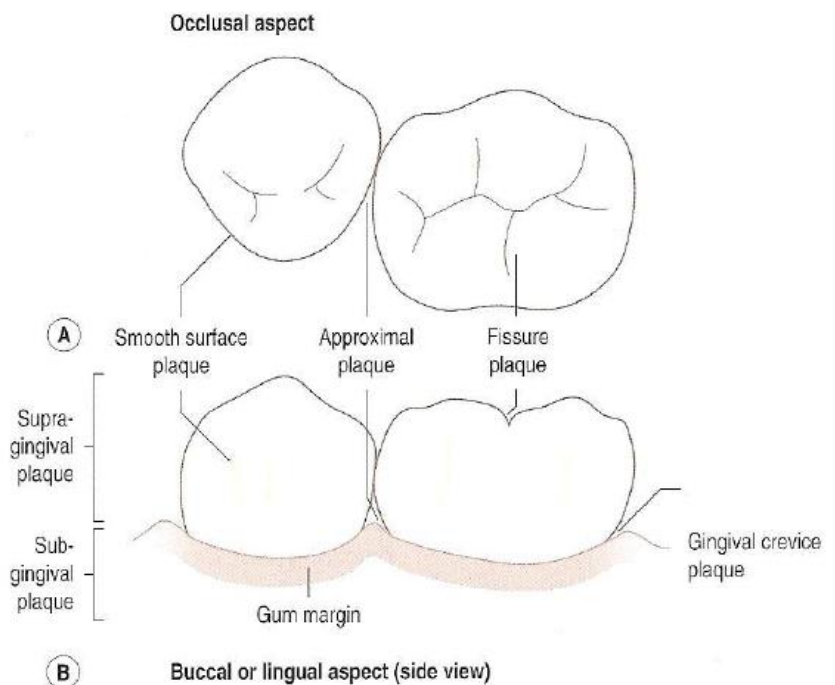

Fig. 2 Figures shows the structure of teeth and the enamel attachment (Marsh \& Martin 1992). 
Organisms found in teeth are Streptococci; Actinomyces; Veinonella; obligate anaerobes; spirochetes; etc. These microbial population may sometimes shows a shift by forming dental caries. Dental caries is one of the major diseased conditions due to different parameters. The dental caries development can be divided into three phases:

$\checkmark$ Attachment of bacteria to a solid surface;

$\checkmark$ Formation of microbial colonies on the surface; and

$\checkmark$ Formation of the mature, sub-gingival plaque biofilms (Marsh et al., 2003).

The diseased teeth or the dental caries may be invaded by carcinogenic organisms forming oral cancers.

Factors responsible for oral cancers:-

Effects of tobacco in oral cavity:-

Tobacco is studied to be containing over 2000 chemicals, amongst which many are responsible for causing oral cancers. Approximately all smokers die from smoking related illnesses (Ebersole JL et al., 2016). As a result of some oral leucoplakic lesions having snuff-induction property, undergoes a drastic transformation to a dysplastic state. These can be further developed to carcinomas or squamous cell variety. The resulting toxic environment formed by the tobacco and nicotine consumptions, manipulates the homeostatic mechanism of the oral micro-flora, thus making a different niche of micro-organisms with pathogenic property (Sharma et al., 2012).

\section{According to US Surgeon General:-}

"There is no risk-free level of exposure to tobacco smoke, and there is no safe tobacco product." (Doll R, Peto, Boreham et al., 2004).

All forms of tobacco are known for the formation of oral cancers. It is known taht about $90 \%$ of the oral cancers are due to tobacco and nicotine consumptions (US Surgeon General, 2000). Both doses and duration period are the damaging parameters for tobacco causing cancers. The most common effective parts by tobacco are: tongue (20\%), gingiva (gums) (18\%), mouth (12\%), lips (11\%), salivary glands (8\%), etc. (Kroes et al., 1999). Oral Leukoplakia, is known to be the most common potentially malignant disorder in the oral cavity (Mecklenburg RE et al., 1996).

Smokers who consume alcohol have a greater risk of oral cancers, results due to synergistic effects (Cancer Research UK, 2011; BDA London, 2000). The oral mucous membrane permeability increases due to consumption of alcohol, which directly or indirectly enhances the carcinogenic effects of tobacco consisting products (Washington, D.C, 2004). Cessation of tobacco reduces the risks of causing oral cancers. About 20 years of the risk can fall for the non-smokers and non tobacco consumers (Warnakulasuriya $S$ et al., 2010).

\section{Gene interactions and tobacco exposure:-}

The three xenobiotic metabolizing enzymes CYP1A1, GSTM1 and GSTT1 significantly alter oral cancer risk singly and in combination. specific tobacco exposures appear to modulate this risk. The long-term SLT ( loose-leaf chewing tobacco) use is prominent for risk of oral cancer some products and much of this risk has been attributed to the presence of TSNAs (tobacco-specific nnitrosamines) or nitrous oxides, which are combustion by-products of fire-curing (Devasena. A et al., 2007; Bush L.P et al., 2001; and Peele D.M et al.,2001). 


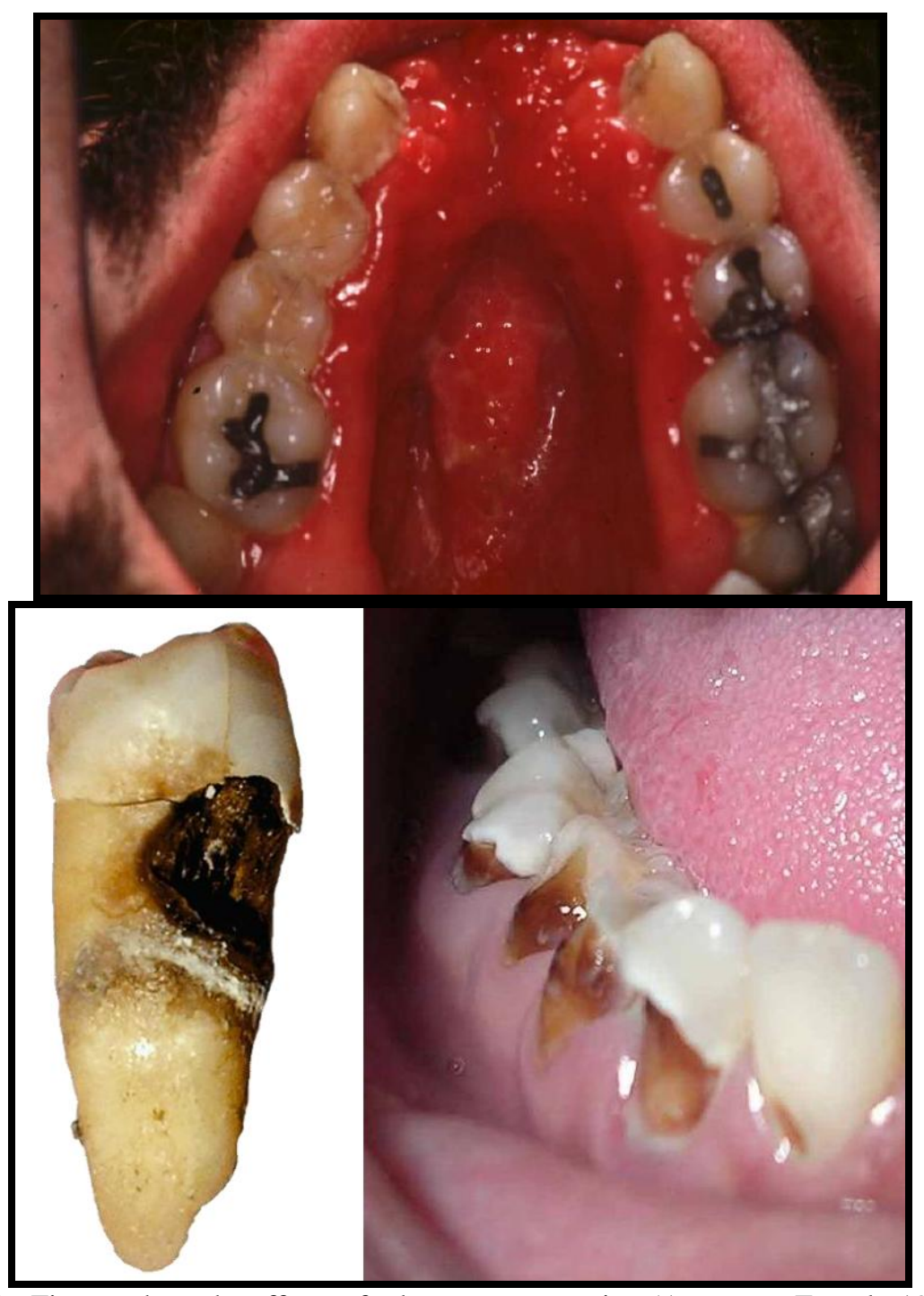

Fig. 3 \& 4:- Figures show the effects of tobacco consumption (Asmussen E et al., 1986).

\section{Changes and mode of action of opportunistic pathogens in mouth:-}

Oral micro-floral bacteria lack an environmental condition which are quickly washed away by saliva or swallowed and destroyed by the acidic juice of the stomach (Rachid et al., 2000). This phenomenon for the oral microbial development, resulting in host infection and dental carries.

There are major three steps for the development of the plaque biofilm -

Attachment of the bacteria to a solid substance:-

The initial attachment is done by pellicle formation. It is a thin quoting of salivary proteins, which attach with the tooth surface. The bacteria-free layer forms on cleaned tooth surfaces [62]. The bacteria attach with the pellicle, forming a slime layer around it Micro-colonies start forming as soon as the bacteria are attached to it. The biofilm proliferates by cell division, doubling the times by early development of plaque formation, finally away from the tooth. More mature biofilms undergo slower development (Gehrig et al., 2003).

\section{Formation of the micro-colonies on the surface:-}

The bacterial colonizers attaches to bacteria, which are pre-attached to the pellicle. Bacteria forms a cluster together resulting in sessile, mushroom-shaped, micro-colonies, attach to the surface of the teeth in narrow base. This mechanism, results in inflammation and swollen gingival margin. The inflammation secrets gingival sulcus or pus (Ebersole et al., 2016). 
The bacteria generally involve are, gram positive cocci or rods, and some gram negative cocci or rods (Marsh et al., 2003).

\section{Formation of mature, sub-gingival plaques:-}

The mechanisms either undergo by the development of tooth attachments or by epithelial attachments. The bacteria adheres with tooth are gram positive with some gram negative cocci or rods (Sansone et al., 1993). Whereas the bacteria involving in epithelial binding are generally gram negative rods and spirochetes (Bowden et al., 1990 and Marsh et al., 1999).

The bacterial infective mode of action is enhancement when the inside mouth area is disturbed. If acid tolerating bacteria, i.e some acidogenic, non-mutans streptococci can also be associated with disease is increased it undergoes rapid metabolism of dietary sugars, enhancing growth and multiplication of the species, associated with enamel health (Loesche et al., 1986 and Becker et al., 2002).

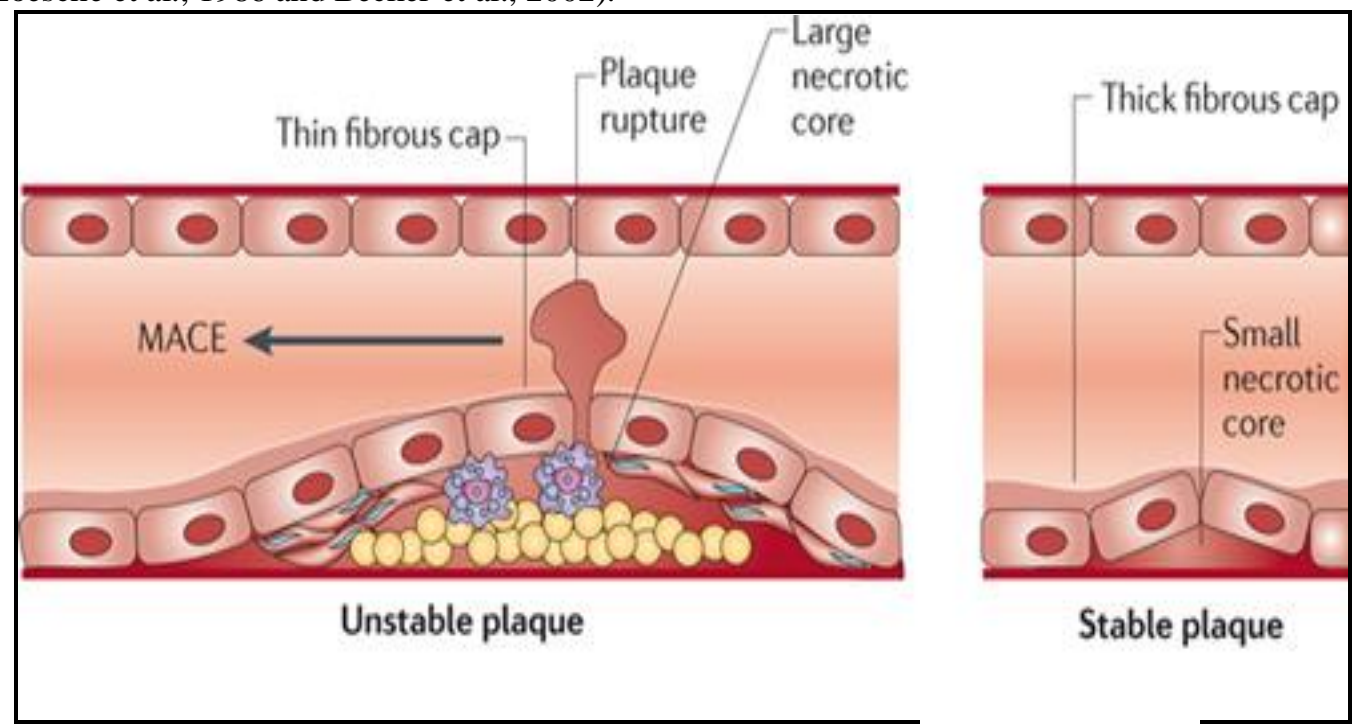

Fig. 5:- Figure representing types of plaque formation (Gupta B et al., 2013).

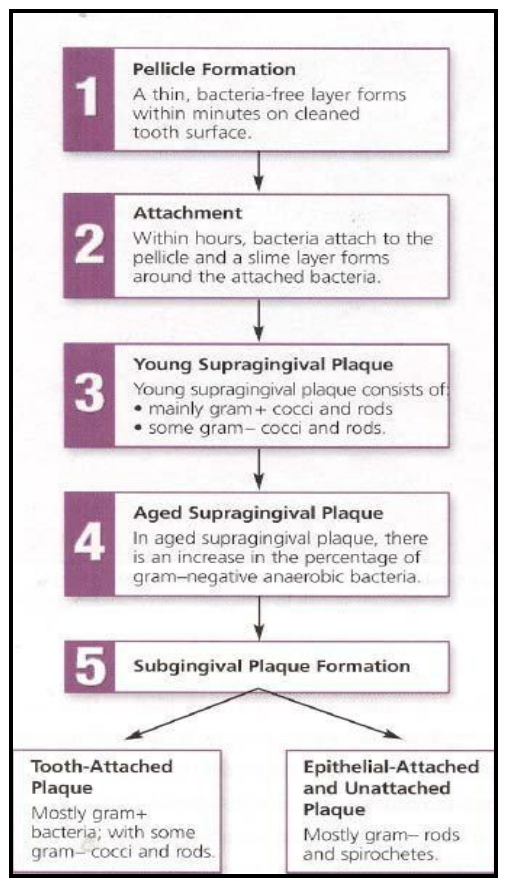

Fig. 6:- Figure showing phases of plaque formation (Gehrig, 2003). 


\section{Sources of carcinogenic pathogens in mouth:-}

Most of the pathogens which are generally associated with host infection do not normally prevail in the healthy host. The pathogens are obtained exogenously to a definite site. It was noted earlier, that the normal homeostatic mechanisms, which maintains the normal livelihood of oral micro-flora. This homeostatic mechanism of normal micro-flora is disrupted, for formation of pathogenic activity and leading to host infections. It was noted that the plaque mediated diseases, are generally caused by the changes in the normal micro-floral inhabitant, which results in enrichment of the "pathogens" within the micro-floral community due to imposition of the strong pressure and suitable environment. These pathogens may undergo mutations or express their carcinogenic genes in order to infect the healthy host and form oral cancers (Marsh et al., 2009).

\section{Environmental factors for oral carcinogenic growth:-}

Stress, physical and mental abuse, nutrition and diet, exposure to toxins, pathogens, radiation and natural and manmade substances as environmental factors and determinants of growth and body composition can contribute to the risk of some human cancers such as oral cancer (Bostwick D.G et al., 2004; Wogan G.N et al., 2004; and Sugiyama.T et al., 2004). Stress is known to activate the body's endocrine or hormonal system which in turn causes changes in the immune system. There is no specific evidence that changes in the immune system caused by stress directly cause cancer. There is strong evidence that stress, physical and mental abuse, increases the risk for oral cancer (Rajkumar T. et al., 2003).

Environmental factors such as viruses, radiation, natural and man-made substances interact with cells, throughout our lives. Mechanism to repair the damage of our genes and healthy lifestyle is essential. However, over time, substances in the environment may cause gene alterations, which accumulate inside our cells. While many alterations have no effect on a person's health, permanent changes in certain genes can lead to cancer (Sharma Nishant et al., 2012). One-third of the cancer risk is thought to be the diet (Doll. $\mathrm{R}$ et al., 1981). Tumour incidence may have a remarkable decrease by consumption of calorie-restricted diet. Vegetables including antioxidants may contribute to the reduction of cancers. Therefore, dietary restrictions may manipulate the proliferation of cancerous prospects. Some foods which are significantly correlated with the oral cancers are milk, meat, cheese, carrot, etc. (MacGregor J.T et al., 1990; and Blount B.C et al., 1997).

\section{Parts included in oral cancers:-}

Oral cancer is one of the leading types of cancers all over the World. India ranks third in common prevalence in women and serves a leading rank among oral cancers of men (Parkin D.M et al., 2002; and Notani P.N et al., 2001). Being in heterogeneous group, oral cancers arise in different parts of the oral cavity, having different predisposing factors, prevalence and treatments. The cancers in the oral cavity are considered under a type of oropharyngeal cancer, including (PCL) Precancerous Lesions and Leukoplakia, etc (Sakaranarayanan. R et al., 1997).

$\checkmark$ Oral cancers are more prevalent in men rather than women, and perform a greater death

$\checkmark$ rate.

$\checkmark$ Approximately $87-90 \%$ of the oral cancer throughout the World are of aged people (45

$\checkmark$ and above).

$\checkmark$ Maximum rate includes the squamous cell carcinomas.

$\checkmark$ Half of the oral cancers are occupied to mouth and about 6-10\% to lips.

$\checkmark$ Internationally, the highest death rates from oral cancer occur in countries in the western

$\checkmark$ Pacific region and Sri Lanka where chewing tobacco is common (Policy Statements: 2011).

Based on the International Classification of Diseases (IDC) oral cancer includes all cancers of the lip, tongue, gingiva, all of the oral mucosa and oropharynx but not cancers of the major salivary glands, hypopharynx and nasopharynx (Washington, D.C, 2004). 


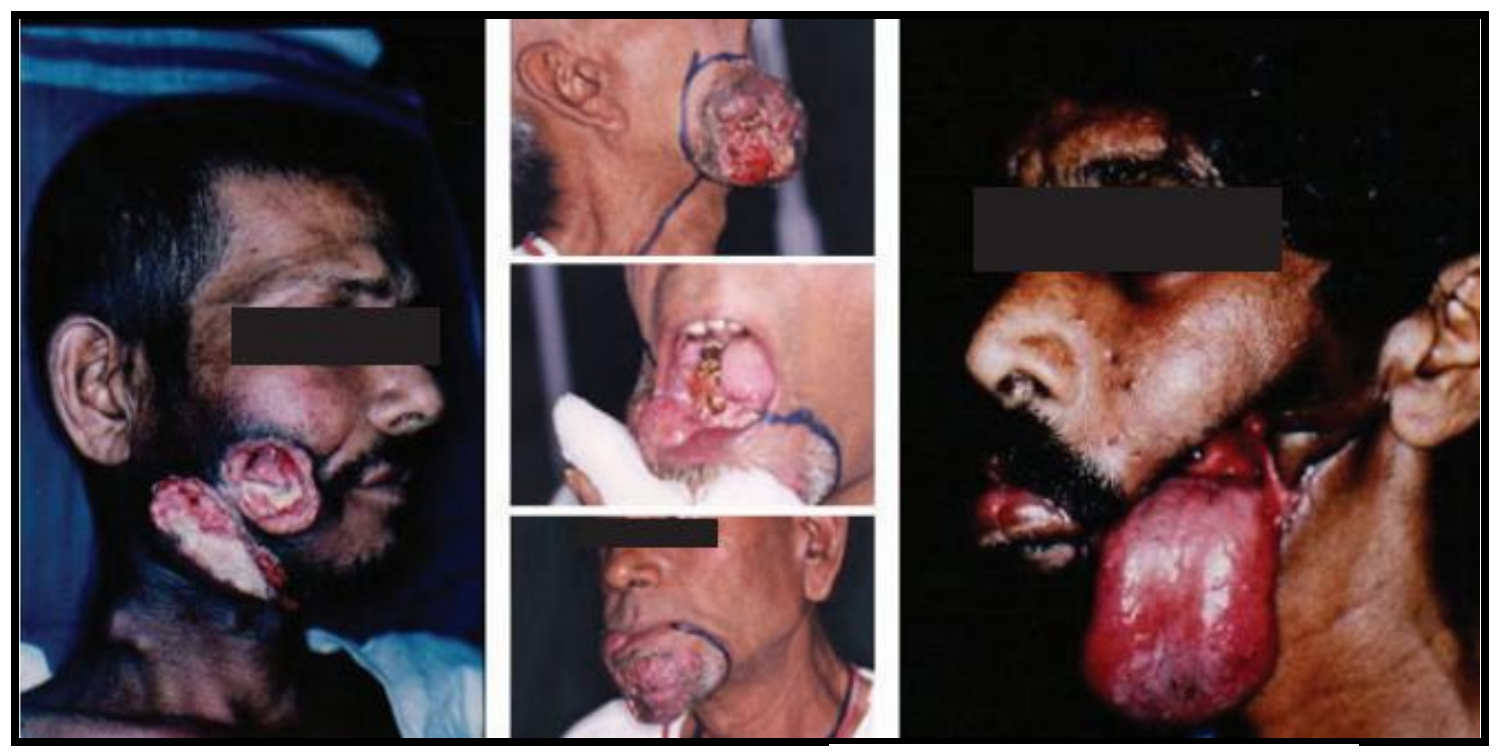

Fig. 7:- Figures show the parts affected by oral cancers (ASH: "Tobacco \& Oral Health", 2012).

Adverse conditions for oral carcinogenic bacterial growth:-
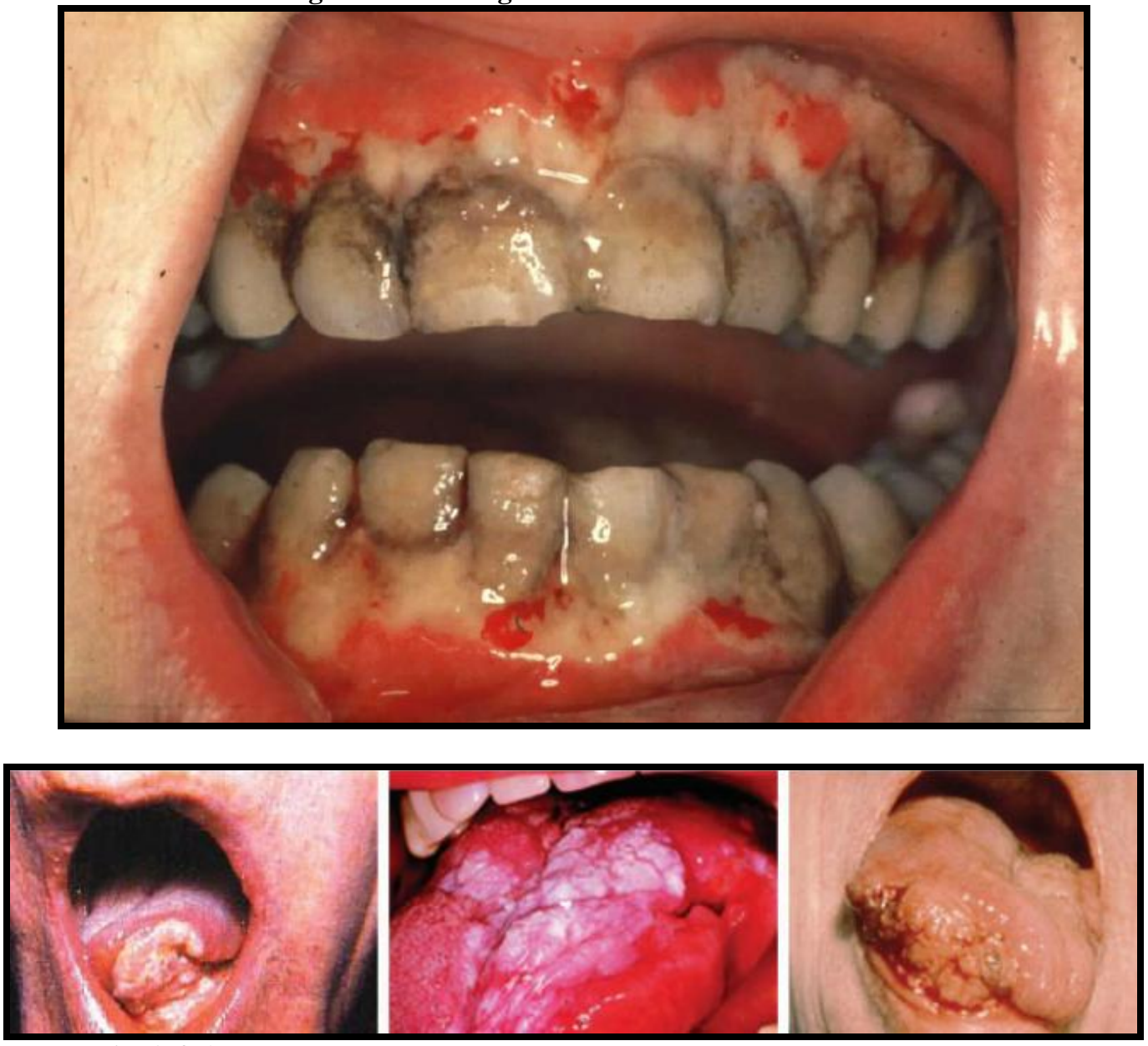

Fig. 8 \& 9:-Figures show the adverse oral cancers symptoms and effects [2]. 


\section{Conclusions:-}

A major habitation of bacteria including micro-floras and opportunistic pathogens are present in the oral cavity. Microbial populations on mouth mucosa differ between salubrious and malignant sites. Certain oral bacterial species are also linked with malignancies due to their ability to induce chronic inflammation. Different bacteria have been proposed to induce carcinogenesis either through induction of chronic inflammation or by interference, either directly or indirectly, with eukaryotic cell cycle and signalling pathways, or by metabolism of potentially carcinogenic substances. Infections include inflammation, sensitivity, redness etc. Therefore it can be concluded that normal micro-organisms prevailing in the normal oral cavity can transform to a pathogenic one under certain factors, may it be chemical or physical. To it the effect of tobacco, nicotine, alcohol, diet, stress, $\mathrm{pH}$ etc. are the enlightened ones. The resulting environment formed by the tobacco and nicotine consumptions, manipulates the homeostatic mechanism of the oral micro-flora, thus making a different niche of micro-organisms with pathogenic property. As India is one of the leading countries in oral cancers, therefore some preventive measures should be taken by the country people.

\section{Ethical approval:-}

Not required as we utilized already published reports.

\section{Acknowledgement:-}

This is to express my immense respect and gratitude towards Techno India University, for the academic support they have provided to me. It would not have been possible without the kind support and help of many individuals and organizations. I am highly indebted to Techno India University, Salt Lake, Kolkata, for their guidance and constant supervision as well as for providing necessary information and also for their support in completing the review project. I would like to extend my sincere thanks to all of them for guiding me to make a successful review on "A comprehensive review on habitat of microbial comparison between normal oral cavity and patients having oral cancers".

\section{Conflict of interest statement:-}

None declared.

\section{References:-}

1. 225, MMBB (2016). "Week10.Pdf". www.uiweb.uidaho.edu. N.p., Web. 10 Jan.

2. Anantharaman, D. et al. (2007). "Susceptibility To Oral Cancer By Genetic Polymorphisms At CYP1A1, GSTM1 And GSTT1 Loci Among Indians: Tobacco Exposure As A Risk Modulator".Carcinogenesis 28.7 : 1455-1462. Web.

3. Asmussen E, Hansen EK. (1986). Surface discoloration of restorative resins in relation to surface softening and oral hygiene. Scand J Dent Res.; 94: 174-7.

4. Becker, M.R., Paster, B.J., Leys, E.J., Moeschberger, M.L., Kenyon, S.G., Galvin, J.L., Boches, S.K., Dewhirst, F.E., Griffen, A.L. (2002). Molecular analysis of bacterial species associated with childhood caries. J Clin Microbiol 40:1001-1009.

5. Beighton D, Smith K, Hayday $\mathbf{H}$ (1986). The growth of bacteria and the production of exoglycosidic enzymes in the dental plaque of macaque monkeys. Archs Oral Biol 31: 829-35.

6. Benoit DS, Koo H, (2016, Apr). Targeted, triggered drug delivery to tumor and biofilm microenvironments. Nanomedicine. 2016 Apr; 11(8):873-9.

7. Blount B.C., Mack M.M.,Wehr C., MacGregor J., Hiatt R.,Wang G.. Wickramasinghe S.N., Everson R. B. And Ames B.N., (1997). Folate deficiency causes uracil misincorporation into human DNA and chromosome breakage: Implications for cancer and neuronaldamage. Proc. Nat. Acad. Sci. USA; 94(1), 32903295 .

8. Bokot-Btsyiv M, Vuckovic $\mathbf{N}$ (2002). Cigarette smoking as a risk factor associated with oral leukoplakia (pdf). Archive of Oncology 10 (2): 67-70.

9. Bostwick D. G., Burke H ., Djakiew D.,Euling S., Ho S. M., Landolph J., Morrison H, Sonawane B., Shifflett T., Waters D. J. and Timms B., (2004). Human prostate cancer risk factors, Can.; 101(10), 23712490.

10. Bowden, G.H. (1990). Microbiology of root surface caries in humans. J Dent Res 69:1205-1210.

11. Briefing, ASH. "Tobacco \& Oral Health" (2012 Jan). www.ash.org.uk. N.p.; Web. 
12. Bush L. P., Cui M., Shi H., Burton H.R.,Fannin F. F. and Lei L., (2001). Formation of tobaccospecific nitrosamines in air-cured tobacco Rec. Adv. Toba. Sci; 27(1),23-46.

13. C. G. Emilson* and D. Bratthall (1976). Journal of cunical microbiology (american society for microbiology), p. 95-98 copyright.

14. Cancer Research UK website (17 September 2011). Oral Cancer Risk Factors. Gandini S, Botteri E, Iodice S, et al. Tobacco smoking and cancer: a meta-analysis. Int J Cancer 2008; 122 (1): 155-64.

15. Cancer Research UK website (17 September 2011). Oral Cancer Risk Factors.

16. Castellsagué X, Alemany L, Quer M, Halec G, Quirós B, Tous S, Clavero O, Alòs L, Biegner T, Szafarowski T, Alejo M. (2016, Jun 1). HPV Involvement in Head and Neck Cancers: Comprehensive Assessment of Biomarkers in 3680 Patients. Journal of the National Cancer Institute.; 108(6):djv403.

17. Doll R. and Peto R., (1981). The causes of cancer. Quantitative estimatesof avoidable risks of cancer in the United States today, J. Nat. Can. Inst., 66(1), 1191-308.

18. D'Souza G, Wentz A, Kluz N, Zhang Y, Sugar E, Youngfellow RM, Guo Y, Xiao W, Gillison ML. (2016, Feb 10). Gender differences in risk factors and natural history of oral human papillomavirus (HPV) infection. Journal of Infectious Diseases.; jiw063.

19. Ebersole JL, Kirakodu S, Novak MJ, Exposto CR, Stromberg AJ, Shen S, Orraca L, Gonzalez-Martinez J, Gonzalez OA, (2016, Feb 1). Effects of aging in the expression of NOD-like receptors and inflammasome-related genes in oral mucosa. Molecular oral microbiology. 2016 Feb 1; 31(1):18-32.

20. Gehrig, J.S. and Willmann, D.E (2003). Foundations of Periodontics for the Dental Hygienist. Philadelphia: Lippincott Williams \& Wilkins 67-73.

21. Gibbons RJ (1989). Bacterial adhesion to oral tissues: a model for infectious diseases. J Dent Res 68: 750-60.

22. Gupta B, Ariyawardana A, Johnson NW (2013, Feb 1). Oral cancer in India continues in epidemic proportions: evidence base and policy initiatives. International dental journal. 63(1):12-25.

23. International Agency for Research on Cancer (2007). IARC Monograph on the evaluation of carcinogenic risk to humans. Smokeless tobacco and some tobacco-specific nitrosamines, Vol 89.

24. Javed F, Warnakulasuriya S. (2016, Jan 31). Is there a relationship between periodontal disease and oral cancer? A systematic review of currently available evidence. Critical reviews in oncology/hematology.; 97:197205.

25. Johnson NW, Bain CA (2000). Tobacco Intervention: tobacco and oral disease British Dental Journal 189: 200-206.

26. Khajuria N, Metgud R (2015). Role of bacteria in oral carcinogenesis. Indian J Dent [serial online] 2015; 6:37-43.

27. Kroes, I., Lepp, P.W., Reiman, D.A (1999). Bacterial diversity within the human subgingival crevice. Proc Natl Acad Sci USA 96(25):14547-14552.

28. Kubota K, Kobayashi W, Sakaki H, Nakagawa H, Kon T, Mimura M, Ito R, Furudate K, Kimura H. (2015, Nov 1). Professional oral health care reduces oral mucositis pain in patients treated by superselective intra-arterial chemotherapy concurrent with radiotherapy for oral cancer. Supportive Care in Cancer. 23(11):3323-9.

29. Lamont RJ, Jenkinson HF (2000). Adhesion as an ecological determinant in the oral cavity. In: Kuramitsu HK, Ellen RP, eds.Oral Bacterial Ecology. The Molecular Basis. Wymondham: Horizon Scientific Press, 13168.

30. Loesche, W.J (1986). Role of Streptococcus mutans in human dental decay. Microbiol Rev 50:353-380.

31. MacGregor J.T., Schlegel R., Wehr C.M., Alperin P. and Ames B.N. (1990), Cytogenetic damage induced by folate deficiency in mice isenhanced by caffeine, Proc. Nat. Acad. Sci. USA, 87(1), 9962-5.

32. Marsh, P.D (1989). Host defenses and microbial homeostasis: role of microbial s interactions. J Dent, Res 68:1567-1575.

33. Marsh, P.D (1999). Microbiologic aspects of dental plaque and dental caries. Dent Clin North Amer, 43:599614.

34. Marsh, P.D (2003). Are dental diseases examples of ecological catastrophes? Microbiology 149:279-294.

35. Marsh, PD and MV Martin (1992). Oral Microbiology. PD Marsh \& MV Martin, Print. Pg 34-90.

36. Mecklenburg RE, Greenspan D, Kleinmann DV et al (1996). Tobacco effects in the mouth. National Cancer Institute \& Institute of Dental Research Guide for health professionals. NIH Publication; No.96-3330.

37. Milwars, M.R (2016). Oral Microflora. M.R.Milwars.

38. Miyano K, Ueno T, Yatsuoka W, Uezono Y, (2016, Apr 1). Treatment for cancer patients with oral mucositis: assessment based on the Mucositis study group of the Multinational Association of Supportive Care 
in Cancer in International Society of Oral Oncology (MASCC/ISOO) in 2013 and proposal of possible novel treatment with a Japanese herbal medicine. Current pharmaceutical design.; 22(15):2270-8.

39. Notani P.N. (2001), Global variation in cancer incidence and mortality. Curr. Sci., 81(1), 465-74.

40. Opportunistic oral cancer screening (2000) - a management strategy for dental practice (pdf). BDA occasional paper, pg 12No.6; London, BDA.

41. Oral Health in America (2000): A Report of the Surgeon General. U.S. Department of Health and Human Services, National Institute of Dental and Craniofacial Research, National Institutes of Health, USA.

42. Parkin D.M., Bray F., Ferlay J. and Pisani P (2002). Global cancer statistics, CA Can. J . Clin. 55(1), 74-108.

43. Peele D.M., Riddick M.G., Edwards M.E.,Gentry J. S., Nestor T. B. (2001), Formation of tobacco : Specific nitrosamines in fluecured tobacco, Rec. Adv. Tobacco. Sci.27(1), 3-12.

44. Petti S. (2016, Jan 1). Oral cancer screening usefulness: between true and perceived effectiveness. Oral diseases.

45. Philip D. Marsh (2000), Microbial Ecology in Health and Disease; 12: 130 - 137.

46. Policy Statements: Oral Diseases Related to Tobacco Use (5 September 2011). The International Association for Dental Research website.

47. Rachid, S., Ohlsen, K., Wallner, U., Hacker, J., Hecker, M. and Ziebuhr, W (2000). Alternative transcription factor sigma (B) is involved in regulation of biofilm expression in a Staphylococcus aureus mucosal isolate. J. Bacteriol. 182:6824-6826.

48. Rahman, Md.Islam,and Hossain (2015), Dhaka Univ. J. Pharm. Sci. 14(1): 103-109.

49. Rajkumar T., Sridhar H., Balaram P., Vaccarella S., Gajalakshmi V., Nandakuma A., Jayshree R., Muñoz N., Herrero R., Franceschi S. and Weiderpass E. (2003), Oral cancer in Southern India : The influence of body size, diet, infections and sexual practices, Eur. J. Can. Prev., 12(1), 135-43.

50. Sankaranarayanan R., Mathew B., Varghese C., Sudhakaran P.R., Menon V., Jayadeep A., Nair M.K., Mathews C., Mahalingam T.R., Balaram P. and Nair P.P, (1997). Chemoprevention of oral leukoplakia with vitamin A and beta carotene : An Ass. Oral. Oncol, 33(1), 231-6.

51. Sansone, C., van Houte, J., Joshipura, K., Kent, R. and Margolis, H.C (1993). The association of mutans streptococci and non-mutans streptococci capable of acidogenesis at a low $\mathrm{pH}$ with dental caries on enamel and root surfaces. J Dent Res 72:508-516.

52. Seoane J, Alvarez-Novoa P, Gomez I, Takkouche B, Diz P, Warnakulasiruya S, Seoane-Romero JM, Varela-Centelles P. (2015). Early oral cancer diagnosis: The Aarhus statement perspective. A systematic review and meta-analysis. Head \& neck.

53. Sharma Nishant *1,2, Srivastav B.R.1 and Shrivatav Archna2 (2012)1. Cancer Hospital and Research Institute, Gwalior (INDIA) 2. College of Life Sciences, Gwalior (INDIA) Received May 15, 2012 Accepted September 28,201. J. Environ. Res. Develop. Journal of Environmental Research And ]; Development Vol. 7 No. $1 \mathrm{~A}$.

54. Sinha DN, Abdulkader RS, Gupta PC. (2016, Mar 15). Smokeless tobacco-associated cancers: A systematic review and meta-analysis of Indian studies. International Journal of Cancer.; 138(6):1368-79.

55. Squier CA, Cox P, Hall BK (1986). Enhanced penetration of nitrosonornicotine across oral mucosa in the presence of ethanol. J Oral Pathol. 15: 276-9.

56. Sugiyama T. (2004), Development of gastric cancer associated with Helicobacter pylori infection,Can. Chemo. Pharmacol. 54(1), 12-20.

57. Taylor \& Francis (2009). Microbial Ecology in Health And Disease. 20th ed. 0891-060X (Print), 1651-2235 (Online).

58. Van der Hoeven JS. (1998). The ecology of dental plaque: the role of nutrients in the control of the oral microflora. In: Busscher HJ, Evans LV, eds. Oral Biofilms and Plaque Control. Amsterdam: Harwood, 57-82.

59. Warnakulasuriya $\mathbf{S}$ et al. (2010). Oral health risks of tobacco use and effects of cessation (pdf). Int. Dent J. 60: $70-30$

60. Washington, D.C. (2004). The health consequences of smoking: a report of the Surgeon General. US Dept. of Health and Human Services,; Washington, D.C.

61. Wiki, micro. "Introduction To Mouth" (2011). www.microwiki.com. Web. 18 July.

62. Wogan G. N., Hecht S. S., Felton J. S., Conney A. H. and Loeb, L. A. (2004), Environmental and chemical carcinogenesis; Sem. Can. Biol.14(1), 473-486. 